\title{
The Potential of Hydrocyclone Application for Mammalian Cell Separation in Perfusion Cultivation Bioreactors
}

\author{
Elsayed A. Elsayed ${ }^{1,2, *}$ and Mohamad A. Wadaan ${ }^{1}$ \\ ${ }^{1}$ Bioproducts Research Chair, Zoology Department, Faculty of Science, King Saud University, 11451 Riyadh, \\ Kingdom of Saudi Arabia \\ ${ }^{2}$ Natural \& Microbial Products Department, National Research Centre, 12311 Dokki, Cairo, Egypt
}

\begin{abstract}
Hydrocyclones have been traditionally applied for long times in many industrial fields, such as in mineral processing and mining, chemical and petrochemical, and food industries. They have many characteristics that favor them as separation system in solid/liquid, gas/liquid and liquid/liquid processes. During the last two decades, they have been evaluated for their possible application in the separation of microbial and mammalian cells. Nowadays, mammalian cells are widely used for the production of a large number of valuable therapeutic proteins, antibodies, hormones and vaccines. This review highlights the potential of the application of hydrocyclones for mammalian cell separation in continuous perfusion biorecators. The discussion will cover the structure of hydrocyclone, mechanism of separation inside hydrocyclones, different theories describing the separation process, as well as the effect of changing different geometrical variables on the efficiency and performance of the separation process. Furthermore, we will focus on the latest developments achieved in the field of separation of living cells in both laboratory and pilot plant cultivation scales.
\end{abstract}

Keywords: Hydrocyclone, cell separation, mammalian cells, perfusion bioreactors, separation efficiency.

\section{INTRODUCTION}

Mammalian cell cultures are currently the major source for the production of large numbers of very high-value recombinant therapeutic proteins, monoclonal antibodies (MAbs), viral vaccines and hormones and thus became as one of the main biofactories in wellness industries [1]. In 2005, the sales market for protein therapeutics reached about $\$$ 55 billion, which represented about 20 percent of the $\$$ 280 billion pharmaceutical market [2]. In 2010 the global market for therapeutic proteins was estimated to reach about $\$ 94$ billion with an annual increasing rate of about 12 percent [3]. Accordingly, highly efficient and reliable production technologies are required to cope with the increased demand for these products. Generally, large-scale commercial mammalian cell cultivations are performed in batch, fed-batch and perfusion processes (Figure 1) [4-7]. The perfusion cultivation mode is generally characterized by the continuous flow of culture medium through the bioreactor, in addition to a cell retention system. In such systems, in situ medium exchange is accomplished, and hence a better control of the culture environment (dissolved oxygen, $\mathrm{pH}$, and substrate concentration) is achieved. Additionally, toxic metabolites are continuously removed with the concomitant recovery of the secreted product, thus minimizing problems caused by product inhibition or by

*Address correspondence to this author at the Bioproducts Research Chair, Zoology Department, King Saud University, 11451 Riyadh, Kingdom of Saudi Arabia; Tel: +966558953623; Fax: +9661146; E-mail: eaelsayed@ksu.edu.sa limited product stability. Cell retention enables higher cell densities (up to $5 \cdot 10^{7} \mathrm{~mL}^{-1}$ ), and, when performed for extended periods, a higher volumetric productivity per bioreactor can be achieved. Furthermore, during the whole fermentation run cell viability can be stably maintained, hence achieving consistent product quality [8-11].

\section{SEPARATION OF MAMMALIAN CELLS IN CONTI- NUOUS PERFUSION CULTIVATION}

Generally, there are different essential properties that affect the suitability of cell retention devices for their application in long-term perfusion cultures [9,12]. Primarily, animal cells are 10-100 times greater than microorganisms and they lack cell wall. Thus, they are more susceptible and highly sensitive to shear stress and outer stimuli. Secondly, they have the tendency to adhere to device surfaces which will result in clogging and fouling problems. An ideal cell retention device should meet most, if not all, of the following features: (1) The device should be able to operate satisfactorily with high retention efficiency for the required duration without replacement or maintenance in order to minimize the risk of contamination; (2) It should not adversely affect cell viability or productivity; (3) Stable, long-term operation should be possible; (4) The device should be easy to clean and sterilize; (5) It should selectively, if possible, retain viable cells while allowing nonviable cells to pass through; and finally (6) It should be suitable for large-scale operation $[11,13]$.

All cell retention devices depend on the same five physical and chemical properties of particles; i.e. size, 


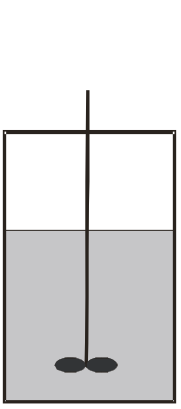

Batch

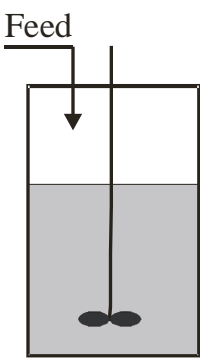

Fed-Batch

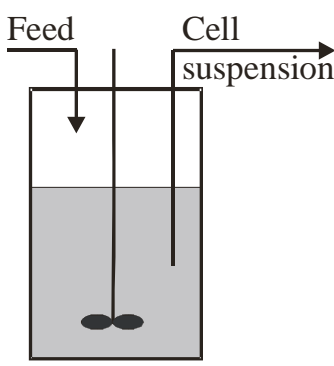

Chemostat

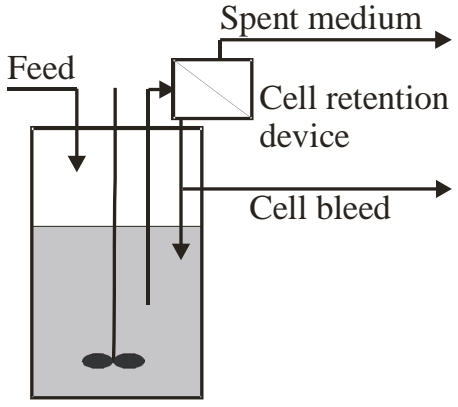

Perfusion

Figure 1: Schematic diagram of different modes of suspended-cell cultivation processes.

density, electrical charges, dielectric constant and surface properties. They are usually based on filtration, e.g. spin filters [14], tangential flow filters [15], dynamic filters [16]; gravitational sedimentation [17,18]; centrifugal action, e.g. centrifuges andhydrocyclones $[19,20]$; ultrasonic $[21,22]$ and dielectrophoretic separation [23,24].

\section{HYDROCYCLONES}

Hydrocyclones are very simple devices, which are used in solid-gas and solid-liquid separation in different industries [25,26]. Although hydrocyclones use the same separation principle as centrifuges, sedimentation in a centrifugal field, they are characterized by having no movable parts. Accordingly, they operate as solid bowl centrifuges with no rotation of the main system. The vortex motion of the suspension is performed by the fluid through its tangential feeding into the cyclone $[9,10,27]$. Hydrocyclones consist of a conical section connected to a cylindrical part, which is fitted with a tangential inlet. The cylindrical part is closed by a plate with an axially installed overflow orifice or vortex finder. The conical portion ends with a circular apex opening or the underflow orifice (Figure 2).

Although the first patent on hydrocyclone separation appeared more than 120 years ago [28], its first industrial application appeared only by the end of the Second World War. The hydrocyclone separation can be divided into three distinct development stages: solidliquid separation (1890-1950), liquid-liquid separation (1950-2000), and the separation of ions and molecules (2000-present) [29]. Generally, hydrocyclones found many applications in mineral processing and mining [30,31], food [32,33], textile and pulp [34], petrochemical [35], electro-chemical [36], as well as biological industries [37]. Hydrocyclones have been originally designed to operate in solid/liquid separation processes; however, they are used nowadays in conventional solid/solid [38], liquid/liquid [39] and gas/liquid separations [40]. Table 1 lists some of the recently developed industrial applications for hydrocyclones.

\subsection{Principle of Separation Inside Hydrocyclones}

The tangential feeding of the suspension to be separated through the inlet opening generates a flow vortex in the conical section of the hydrocyclone. This vortex creates a centrifugal force and results in the dispersion of the particles, or cells, across the whole

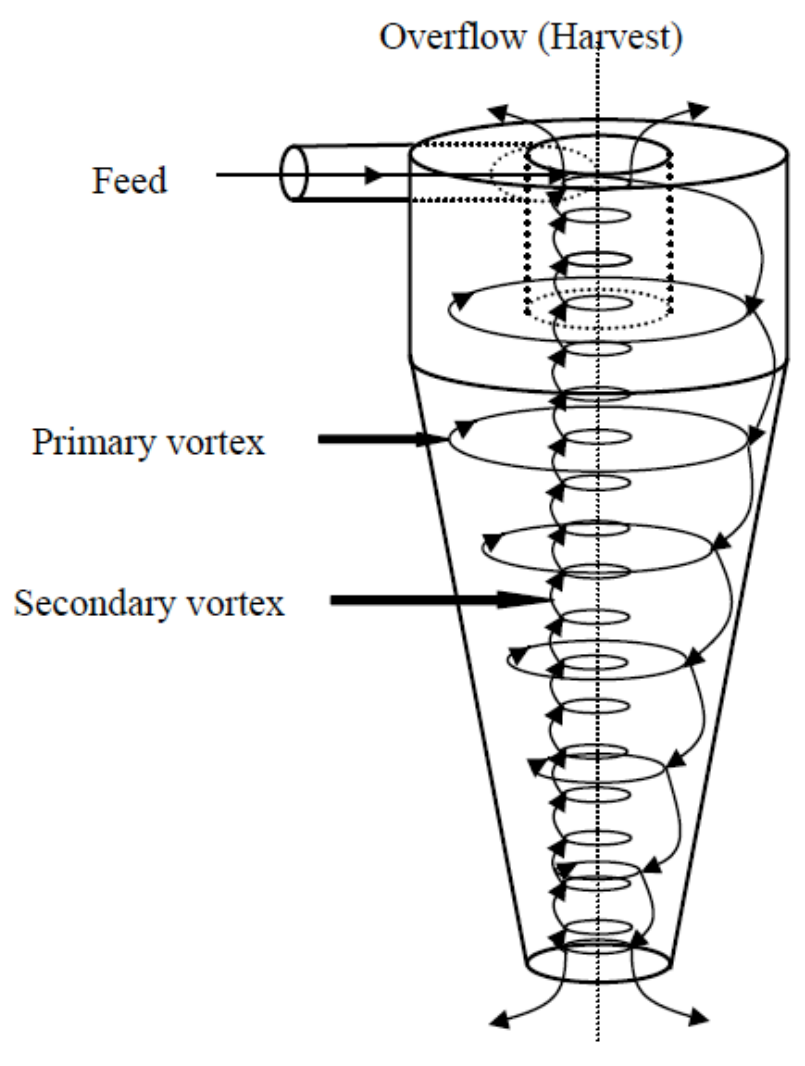

Underflow (Concentrate)

Figure 2: Schematic diagram of a typical hydrocyclone [11]. 
Table 1: Recent Industrial Applications of Hydrocyclones

\begin{tabular}{|c|c|}
\hline Application & References \\
\hline Material disposal, collection of heavy metals ( $\mathrm{As}, \mathrm{Cd}, \mathrm{Cu}, \mathrm{Hg}, \mathrm{Pb}, \mathrm{Zn}$ ) from pyrite ashes & [41] \\
\hline Adsorption of organics with nitrogen and sulfur from wastewater & [42] \\
\hline Treatment of laboratory wastewater mainly containing nitrate & [43] \\
\hline Remediation of oil-contaminated soil & [44] \\
\hline Washing of soil contaminated by a variety of heavy metals and radioactive contaminants & [45-47] \\
\hline Improvement of the irrigation system & [48] \\
\hline Oil-water separation & [49] \\
\hline Purifying coke-cooling wastewater & {$[50,51]$} \\
\hline Starch-protein separation from chickpea flour & [52] \\
\hline Separation of invasive mudsnails from aquaculture waters & [53] \\
\hline Integrityof animal and microbial cells & [54] \\
\hline Separation of mammalian cells & {$[11,55]$} \\
\hline
\end{tabular}

cross-sectional area $[26,56]$. At that point, the next separation process is characterized by the development of two equally important stages: (1) separation of solids from the main flow and their migration to the boundary layer on the wall, and (2) the removal of the separated solids from the wall into the apex and out of the cyclone. A small fraction of the flow will form a cross-circuit flow below the top cover and bypass the vortex; consequently, any particles in this flow will then directly pass through into the overflow. Contrary, most of particles, or cells, will go through the outer vortex under the influence of the centrifugal forces. Hence, the centrifugal forces must be greater than the drag forces to drive particles radially towards the wall; otherwise they will tend to move radially inward. Since centrifugal and drag forces are proportional to particle volume and size, respectively, therefore the separation performance of hydrocyclone is supposed to be strongly particle-size dependent [57]. This means that large particles will be readily separated than fine ones, which may not reach the boundary layer by the time the outer vortex reaches the bottom of the cone. Upon reaching the bottom of the cone, the outer vortex flow and its fine particles feed across into the inner vortex. Moreover, some of the fine particles may be able to leave the inner vortex resulting in a certain amount of solid circulation, while others will leave with the overflow. The boundary layer and its particle content move downwards into the apex of the cone, where they leave from the underflow orifice. The separation in hydrocyclones is not affected by gravity; particles move into the boundary layer under the influence of the flow itself [58-60].
Recently, the development of computer power and the use of computational fluid dynamics (CFD) allowed a better understanding of fluid flow inside hydrocyclones, and hence their separation mechanism and performance [61-64]. CFD modeling of hydrocyclones involves prediction of velocities of the liquidphases, profiles of the suspension concentrations, turbulent viscosities and particle velocities, as well as swirling flow patterns inside hydrocyclones $[65,66]$.

\subsection{Separation Theories of Hydrocyclones}

Many theories have been developed and proposed to explain the separation process inside the hydrocyclones. These theories are based either on actual physical models derived from first principles, or models derived as empirical equations from linear regression analysis. With this regard, three major theories can be described.

\subsubsection{Equilibrium Orbit Theory}

This theory is based on the concept of the equilibrium radius of the particle, and the fact that the motion inside the hydrocyclone is developed by the liquid flow itself and not forced as in the case of centrifuges. Inside hydrocyclones, the particle will find a position in an equilibrium orbit depending on the equilibrium between the radial velocity of the fluid toward the center and the tangential velocity of the liquid. Accordingly, larger particles will be found toward the outside and enter the outer vortex moving downwards toward the underflow orifice. Smaller particles, which will be found toward the center, will enter the inner fluid vortex moving upwards toward the 
vortex finder and will be then removed through the overflow orifice [37,57]. Due to very short residence times (usually $0.03 \mathrm{~s}$ ) and high solid concentrations inside the hydrocyclone, the equilibrium orbits may not be achieved. Moreover, this theory takes no account of the turbulences, which may affect the separation process [59].

\subsubsection{Residence Time Theory}

This theory describes the dependence of particles entering the cyclone at the inlet centre on its residence time, and hence whether they will settle to cyclone wall reporting to the underflow. This theory takes into account non-equilibrium conditions [67]. However, the residence time theory does not consider the effect of particle concentration, the so-called hindered settling. Moreover, it neglects the inertial effects and radial fluid flow.

\subsubsection{Crowding Theory}

This theory describes hydrocyclone separation of particles at higher feed concentrations. It assumes that the size distribution of the feed and the underflow determine the separation efficiency. Accordingly, any cut size within the feed size distribution can be obtained by controlling the dimensions of the outlet $[68,69]$.

\subsection{Effect of Hydrocyclone Geometry on its Performance and Efficiency}

During the last three decades, many investigations have been carried out to study the effect of changing the geometrical dimensions (Figure 3 ) on the hydrocyclone performance. Nowadays, it is well established that the structure of the hydrocyclone is the determining factor [33]. Table 2 summarizes the effects of changing different hydrocyclone dimensions on the separation process.

Many attempts have been carried out to improve the separation efficiency by changing the structure of the hydrocyclone. Jirun et al. [70] inserted a solid cone into the hydrocyclone resulting in an increase in the performance as well as reduction of energy loss through the stabilization of the tangential flow and the omission of air core. Furthermore, a spiral inner surface was developed to improve the separation sharpness, where the boundary layer flow was interrupted [71]. Bai et al. [72] applied a small-diameter hydrocyclone for the separation of small particles.

\subsection{Biological Applications of Hydrocyclones}

Hydrocyclones have been traditionally and widely used for a long time in mineral processing industry [73]. They have been generally used for suspension concentration, liquid clarification, thickening, classification, sorting of solids by size and density, liquid-liquid separation and liquid-gas separation [29]. This can be attributed to their simple design, low cost, easy operation and low maintenance $[59,74,75]$. Although, many investigations have been carried out to study the separation and the working principles of hydrocyclones, however, most of this work was related to their application in mineral processing industry [58,76-78].

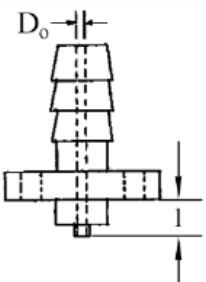

(a)

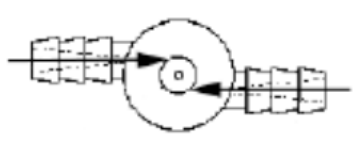

(b)
- $D_{c} \quad$ Cylinder diameter

- $D_{\mathrm{i}} \quad$ Inlet diameter

- $D_{0} \quad$ Overflow pipe diameter

- $D_{\mathrm{u}} \quad$ Underflow diameter

- L Hydrocyclone length

- $L_{1} \quad$ Cylinder length

- I Immersion depth

- $\theta \quad$ Hydrocyclone cone angel

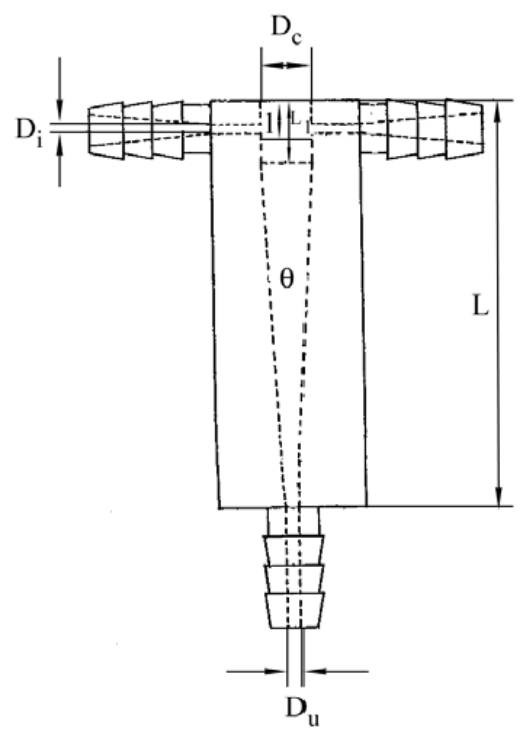

(c)

Figure 3: Schematic diagram of a typical double-inlet hydrocyclone with its corresponding geometrical dimensions, (a) cover Side-view, (b) body Top-view, (c) body Side-view [11]. 
Table 2: Effect of Changing the Geometry of the Hydrocyclone on the Separation Performance [11]

\begin{tabular}{|c|c|c|c|}
\hline \multirow{2}{*}{ Geometrical dimension } & \multicolumn{3}{|c|}{ Performance of hydrocyclone } \\
\cline { 2 - 4 } & Increased capacity & Increased separation efficiency & Increased flow ratio \\
\hline \hline Cyclone diameter & Increase & Decrease & - \\
\hline Inlet diameter & Increase & Decrease & Decrease \\
\hline Overflow diameter & Increase & Decrease & Increase \\
\hline Body length & Increase & Increase & Decrease \\
\hline Vortex finder length & Decrease & Decrease & - \\
\hline Cone angle & - & Decrease & \\
\hline
\end{tabular}

In the last two decades, hydrocyclones have been tested for their application in solid-liquid separation processes involving biological materials. They have been used in the food industry for starch refining, recycling of silica gel for filters in the brewing industry, separation of gossypol from cottonseed protein in cottonseed oil processing, and as multi-stage separator systems for soluble coffee production $[26,60]$. Additionally, hydrocyclones have been applied in the separation of starch-protein from chickpea flour with a separation efficiency of $99.8 \%$ [52], as well as the separation of invasive species from aquacultures in fish hatcheries [53,79,80]. Recently, Show et al. [81] used hydrocyclones among four different centrifugation systems in the process of algal biomass separation and dryness.

On the other hand, hydrocyclones have been used to separate living microbial cells in continuous yeast cell cultivation and in beer industry $[82,83]$. Cilliers and Harrison [37] investigated the application of minihydrocyclones in the concentration of yeast suspensions. They studied the effect of several process parameters, e.g. pressure, temperature as well as hydrocyclone geometry on the recovery and concentration of yeast cells. Moreover, Weuster-Botz et al. [84] developed a fermentation process with high oxygen transfer for the continuous methanol controlledproduction of formate dehydrogenase with Candida boidinii. They applied three geometrically similar cyclones with different liquid volumes $(0.5,2.5$ and $15 \mathrm{~L}$ ) and obtained more than $100 \%$ improvement in dry cell mass concentration and about $100 \%$ improvement in the enzyme space-time yield. Only two years later, a new method for yeast recovery in batch ethanol fermentation has been developed. This method uses a filtration method followed by separation of yeast from filter aid using hydrocyclones [85].
Medronho et al. [86] investigated the separation of both microorganisms and mammalian cells depending of CFD-based numerical simulation of hydrocyclones. Their studies revealed the presence of a cylindrical air core running the whole length of the cyclone, which resulted from the low-pressure region developed along the central axis. Additionally, they found that Escherichia coli and Saccharomyces cerevisiae cells could not be efficiently separated with the tested hydrocyclone. However, they were able to separate the BHK-21 mammalian cell line using a $10 \mathrm{~mm}$-Bradley hydrocyclone with separation efficiencies as high as $90 \%$.

In another study, a hydrocyclone with $15 \mathrm{~mm}$ internal diameter was applied for the separation of Saccharomyces cerevisia cells from the fermentation broth [87]. The authors obtained a better separation efficiency of 3.84 ( $\mathrm{g}$ cell dry weight in: underflow/overflow) at a volumetric flow rate of about $112 \mathrm{~cm}^{3} / \mathrm{s}$. In 2012, Bicalho et al. [88] applied three hydrocyclone modules with different geometries for the separation of yeast cells from fermentation broth. Their work aims at developing empirical mathematical models that describe capacity, total separation efficiency and flow ratio as functions of different geometric variables and pressure drops. They obtained total separation efficiencies between $36.54 \%$ and $92.02 \%$, with capacity range from 0.1183 to 0.4579 $\mathrm{m}^{3} / \mathrm{h}$ and flow ratios ranging from $31.74 \%$ to $84.30 \%$. They also found that the maximum centrifugal forces generated within these devices only reduced cell viability by about $7 \%$. Very recently, Pinto et al. [89] investigated the application of two commercial hydrocyclones (Doxie ${ }^{\circledR}$ Type-A and $A K W \AA$ type RWK21) for the separation of $S$. cerevisiae cells from fermentation broth under different operation parameters, i.e. inlet pressure, underflow pressure, and the underflow diameter. Their results showed that the Doxie hydrocyclone gave better separation 
performance up to $89.13 \%$ with a processing capacity of more than $239.25 \mathrm{~kg} / \mathrm{h}$.

\subsection{Application of Hydrocyclones for Separation of Mammalian Cells in Perfusion Cultivations}

During the last decade, the application hydrocyclones for separating mammalian cells in continuous perfusion bioreactors has been evaluated. Hydrocyclones possess many advantages that make them suitable competitors for other cell separation devices. The fact that they do not contain any movable parts favors them in terms of contamination problems. They are easy to install, require very limited space, in situ sterilizable and easy to clean and reuse. Moreover, they are easily manufactured and modified and provide stable, long-term operation $[11,90]$.

Hydrocyclone separation is based on the generation of centrifugal sedimentation that can reach a maximum of several thousand times the force of gravity, which is similar in magnitude to the centrifugal forces used in centrifuges. Accordingly, the generated shear forces or the rapid pressure drop inside the hydrocyclone can have damaging effect on the cells. Nevertheless, it has been found that low shear operating hydrocyclones does not appear to damage the cells, which indicates that hydrocyclones running at moderate conditions have a potential for cell separation in animal cell continuous cultivations [54].

In 2000, hydrocyclone was evaluated for the first time for mammalian cell separation [91]. The authors investigated the separation of HeLa cells by three different hydrocyclones (10 mm-Dorr-Oliver, $10 \mathrm{~mm}$ Mozley and $7 \mathrm{~mm}$-Bradley) working at pressure drop ranging from 1 to 4 bar. They showed that until a pressure drop of 4 bar, HeLa cells were not adversely affected. These results were explained based on the fact that cells have a very short residence time inside hydrocyclones (0.03-0.1 s), therefore, cells are only subjected to the generated shear stress for a very short time. Additionally, applying the maximum pressure of 4 bar gave a separation efficiency of $81 \%$ using the DorrOliver hydrocyclone. They were also able to achieve separation efficiencies of about $94 \%$ at moderate pressure drop (2 bar) by connecting two hydrocyclones together. Despite the fact that the authors used commercially available hydrocyclones (not specially designed for animal cell separation), their results reflected the effect of hydrocyclone geometry optimization on their potential application in perfusion cultures.
In 2001, Jockwer et al. [92] published their work on the separation of animal cells using hydrocyclone. They studied nine different hydrocyclone geometries specially designed by computational fluid dynamics for mammalian cell separation. They reported a decrease in the viability of separated $\mathrm{CHO}$ cells ranging from $5-12 \%$ at 1 bar and $7-21 \%$ at 1.35 bar. However, higher separation efficiency of $94.2 \%$ was obtained with a hydrocyclone having an underflow orifice diameter of $2.5 \mathrm{~mm}$ and an overflow pipe diameter of $2.0 \mathrm{~mm}$. Furthermore, the authors showed, for the first time, that hydrocyclone can be used as a perfusion system in continuous cultivation mammalian cells using bubblefree membrane bioreactors. They were able to cultivate $\mathrm{CHO}$ cells for 23 days with their optimal hydrocyclone configuration with a viability range of more than $90 \%$. The viable cell concentration increased by $50 \%$ with more than 3-fold increase in the concentration of recombinant antibody.

Few years later, Elsayed [11] extensively evaluated the application of specially-designed hydrocyclones [93] for the separation of mammalian cells in continuous perfusion cultivation. The author investigated different hydrocyclone geometries (different overflow and underflow orifices diameter), operating parameters (pressure drop and flow rate) as well as different cell lines (HeLa, CHO, NSO, BHK21). The author proved that changing the hydrocyclone diameter has a great impact on the separation efficiency of the hydrocyclone with regard to cell viability. Moreover, it was shown that hydrocyclone separation gave similar results when the perfusion process was compared with traditional cell separation (hollow-fiber membrane).

Furthermore, Elsayed et al. [94] published their work on hydrocyclone separation for $\mathrm{CHO}$ and HeLa cells cultivated on lab scale $(6 \mathrm{~L})$ and pilot scale $(30 \mathrm{~L})$ bioreactors. The authors demonstrated that hydrocyclone can be applied in continuous perfusion cultivations for the production of monoclonal antibodies. They were able to maintain an average cell concentration of up to 10 million per $\mathrm{mL}$ with cell viability above $93 \%$. The hydrocyclone was operated at pressure drop ranging from 0.85 to 1.0 bar, resulting in separation efficiency above $85 \%$, and a maximum dilution rate of 1.83 reactor volume $\mathrm{d}^{-1}$.

In 2006, Elsayed et al. [95] characterized the performance of a hydrocyclone having an internal volume of $2.56 \mathrm{~cm}^{3}$ with regard to flow split and flow ratio. Depending on the pressure drop applied, the authors were able to separate BHK and HeLa cells with 
a separation efficiency ranging from 77 to $97 \%$. Moreover, their results demonstrated for the first time, that only cells passing from the primary vortex downwards into the inner secondary vortex and from there upwards could be damaged. Consequently, this has no impact on the overall cell viability in the bioreactor, since the overflow cell fraction is leaving the bioreactor. Additionally, they proved that continuous hydrocyclone application (for $3 \mathrm{~h}$ ) has no adverse effect on cell viability or apoptotic cell fractions, and that cells suffer from the shear stress inside the hydrocyclone only for the time required for each cell to pass through the hydrocyclone. In other words, the time required for the whole bioreactor content to pass through the hydrocyclone, where the cells adapt themselves to the new conditions.

Pinto et al. [55,96] investigated the effect of hydrocyclone separation using different geometries on the viability and integrity of $\mathrm{CHO}$ cells by following cell viability, released lactate dehydrogenase (released in case of cell lysis) and the concentration of apoptotic cells. Their results showed that cells maintained higher viabilities (above 97\%) with a selective separation for viable cells. They also used the same hydrocyclone for the separation of NS0 cells in $300 \mathrm{~L}$ bioreactors for the production of a monoclonal antibody (unpublished data).

In 2010, the specially designed hydrocyclone which has been applied in the work cited from 2001 to 2008 has been commercialized by Sartorius-BBI Systems $\mathrm{GmbH}$, Melsungen, Germany. This system (Figure 4) was then evaluated for cell separation in the cultivation of a hybridoma cell line producing a monoclonal antibody in protein free medium [97]. The $10 \mathrm{~cm}$ hydrocyclone was directly installed on top of highlyautomated, balance-controlled 20-L and 200-L stirred tank bioreactors. The hydrocyclone was operated at a flow rate ranging from 0.3 to $0.5 \mathrm{~L} \mathrm{~min}^{-1}$, giving a maximum process-specific perfusion performance of 450-720 L d ${ }^{-1}$.

Elsayed and Wagner [98] evaluated hydrocyclone for the separation of SP-2/0 cells in perfusion bioreactors under different operating pressure drops. According to the applied pressure drop, the authors achieved from 3.5- to 5-fold increase in the cell concentration from the batch cultivation. The cells were not adversely affected and the viability ranged from $92-$ $98 \%$. Concerning process performance, the hydrocyclone was operated with a separation efficiency ranging from 89 to $95 \%$. Moreover, results showed that the

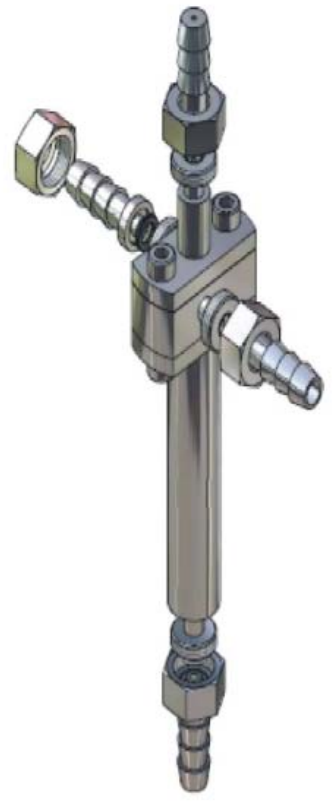

Figure 4: Prototype of mammalian cell culture hydrocyclone [97].

hydrocyclone preferably separates viable cells into the underflow, and hence, back to the bioreactor, resulting in an improved system viability and product quality. Furthermore, Elsayed et al. [99] investigated the effect of feed flow pulsation on cell viability and separation efficiency. They changed the pulsation-free feed pumphead to a conventional pulsating pumphead. The results revealed that both pumpheads gave comparable results in terms of hydrocyclone separation efficiency and cell viability under different investigated pressure drops.

\subsection{Scaling Up of Hydrocyclones}

Concerning mammalian cell perfusion cultivations, there is always a need to scale up the fermentation process to cope with higher demands for the production of pharmaceutical proteins. Usually, scaling up is required in processes requiring higher dilution rates or applying the hydrocyclones for larger mammalian cell bioreactors. Accordingly, it can be proposed that the hydrocyclone itself should be scaled up. Normally, scaling up is usually obtained by changing the configuration of the device used for cell retention. However, in the case of hydrocyclones this concept cannot be applied [11,37]. The performance of the separation process is strictly controlled by the geometrical dimensions of the hydrocyclone itself. Many reports described the effects of changing the geometries of the hydrocyclone on the separation performance $[76,77,100,101]$. 


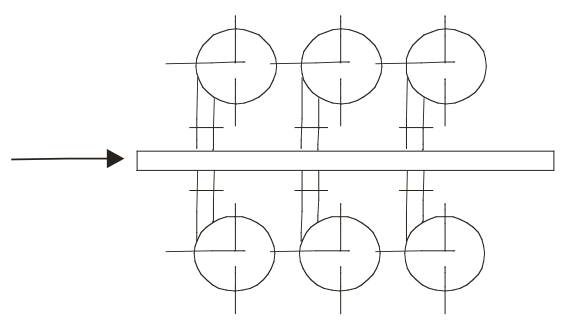

Linear arrangement (plan view)

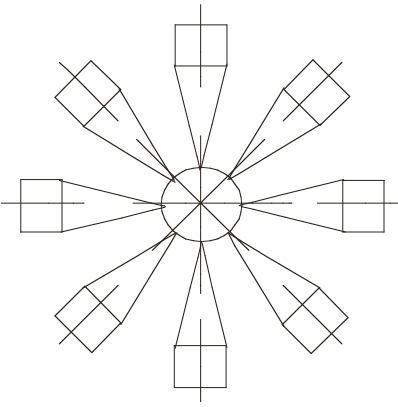

Circular arrangement (plan view)

Figure 5: Different arrangements used for hydrocyclone batteries [11]

As described in Table 2, it is shown that in order to have higher separation efficiencies, most of the hydrocyclone geometries, except for the body length, should be decreased. Hence, the smaller the nominal diameter of the hydrocyclone is, the higher the efficiency will be and the smaller the handling capacity as well [102]. In such case, another concept should be applied, which is the use of the so-called multi-cyclone arrangements or parallel hydrocyclones. Multi-cyclone arrangements have been largely used on industrial scale [59,102]. In the multi-cyclone arrangements, hydrocyclones are connected together to cope with the large flow rates required. This may be done by linearly or circularly arranging a series of two or more hydrocyclones. Figure 5 shows linear and circular arrangements of the hydrocyclone batteries.

\section{CONCLUSIONS AND FUTURE PROSPECTS}

Hydrocyclones have unique characteristics that make them attractive devices to replace the traditional cell separation equipments that have been used in mammalian cell perfusion bioreactors. Hydrocyclones are characterized by their small size, ease of installation, suitability for in situ sterilization, and easy cleaning and reusing. These all together make them attractive separation devices in bioprocess industries. In addition, they do not have movable parts which reduced the risk of contamination during operation. This make them also easily approved to be used in cGMP facilities. They have been evaluated over the last two decades for cell separation in perfusion production cultivations with different mammalian cell lines under different operational conditions. However, with the exception of few reports, most of the published work is related to laboratory investigations. Therefore, further studies on their potential use in semi-industrial and industrial scale should be investigated to evaluate and understand the scalability of these devices. Once they are further studied and optimized for large scale mammalian cell separation, they will change in part the current pharmaceutical practice regarding cell separation systems applied in long-term perfusion cultivations.

\section{REFERENCES}

[1] Sarmidi MR, El Enshasy HA. Biotechnology for wellness industry: Concepts and biofactories. Int $\mathrm{J}$ of Biotechnol Wellness Industries, 2012; 1: 3-28. http://dx.doi.org/10.6000/1927-3037.2012.01.01.01

[2] Dimitrov DS, Marks JD. Therapeutic antibodies: Current state and future trends - Is a paradigm change coming soon? Methods Mol Biol, 2009; 525: 1-27. http://dx.doi.org/10.1007/978-1-59745-554-1 1

[3] Strohl WR. Therapeutic monoclonal antibodies: Past, present and future. In: An Z, editor. Therapeutic monoclona antibodies. From bench to Clinic. New Jersey: Wiley \& Sons, 2009. p. 3-50.

http://dx.doi.org/0.1002/9780470485408.ch

[4] Pringle AT. Fermentation and mammalian cell culture. In: Klegerman ME, Groves MJ, editors. Pharmaceutical biotechnology, fundamentals and essentials. Illinois: Interpharm Press Inc., 1992; p. 115-37.

[5] Tokashiki M, Yokoyama S. Bioreactors designed for anima cells. In: Hauser $\mathrm{H}$, Wagner $\mathrm{R}$, editors. Mammalian cell biotechnology in protein production. Berlin: Walter de Gruyter, 1997; p. 279-317.

[6] Zhang J, Collins A, Chen M, Knyazev I, Gentz R. Highdensity perfusion culture of insect cells with a BioSep ultrasonic filter. Biotechnol Bioeng, 1998; 59: 351-9. http://dx.doi.org/10.1002/(SICI)1097-

\section{0(19980805)59:3<351::AID-BIT11>3.0.CO;2-H}

[7] Sandig V, Rose T, Winkler K, Brecht R. Mammalian cells. In: Gellissen G, editor. Production of recombinant proteins: Novel microbial and eukaryotic systems. Weinheim: Wiley$\mathrm{VCH}, 2005 ;$ p. 233-52.

http://dx.doi.org/10.1002/3527603670

[8] Su WW. Bioreactors, perfusion. In: Spier RE, editor. Encyclopedia of cell technology. Vol 1, New York: Wiley, 2000; p. 230-42.

[9] Castilho LR, Medronho RA. Cell retention devices for suspended-cell perfusion cultures. In: Schügerl K, Zeng A-P, editors. Tools and applications of biochemical engineering science. Adv Biochem Eng Biotechnol, Vol. 74, Berlin: Springer Verlag, 2002; p. 129-69.

http://dx.doi.org/10.1007/3-540-45736-4 7 
[10] Voisard D, Meuwly F, Ruffieux P-A, Baer G, Kadouri A. Potential of cell retention techniques for large-scale highdensity perfusion culture of suspended mammalian cells. Biotechnol Bioeng, 2003; 82: 751-65.

http://dx.doi.org/10.1002/bit.10629

[11] Elsayed EA. Application of hydrocyclone for cell separation in mammalian cell perfusion cultures. Göttingen: Cuvillier; 2005.

[12] Woodside SM, Bowen BD, Piret JM. Mammalian cell retention devices for stirred perfusion bioreactors. Cytotechnology, 1998; 28: 163-75. http://dx.doi.org/10.1023/A:1008050202561

[13] Castilho LR, Medronho RA. Animal cell separation. In: Castilho LR, Moraes AM, Augusto EFP, Butler M., editors. Animal cell technology: From biopharmaceuticals to gene therapy. New York: Taylor \& Francis, 2008; p. 273-93.

[14] Deo YM, Mahadevan MD, Fuchs R. Practical considerations in operation and scale-up of spin-filter based bioreactors for monoclonal antibody production. Biotechnol Prog, 1996; 12: 57-64.

http://dx.doi.org/10.1021/bp950079p

[15] van Reis R, Gadam S, Frautschy LN, et al. High performance tangential flow filtration. Biotechnol Bioeng, 1997; 56: 71-82. http://dx.doi.org/10.1002/(SICI)10970290(19971005)56:1\&lt;71::AID-BIT8\&gt;3.0.CO;2-S

[16] Castilho LR, Anspach FB. CFD-Aided design of a dynamic filter for mammalian cell separation. Biotechnol Bioeng, 2003; 83: 514-24.

http://dx.doi.org/10.1002/bit.10697

[17] Sato S, Kawamura K, Fujiyoshi N. Animal cell cultivation for production of biological substances with a novel perfusion culture apparatus. J Tissue Cult Method, 1983; 8: 167-71. http://dx.doi.org/10.1007/BF01665880

[18] Hülscher M, Scheibler U, Onken U. Selective recycle of viable animal cells by coupling of airlift reactor and cell settler. Biotechnol Bioeng, 1992; 39: 442-6.

http://dx.doi.org/10.1002/bit.260390410

[19] Hamamoto K, Ishimaru K, Tokashiki M. Perfusion culture of hybridoma cells using a centrifuge to separate cells from the culture mixture. J Ferment Bioeng, 1989; 67: 190-4. http://dx.doi.org/10.1016/0922-338X(89)90121-9

[20] Takamatsu H, Hamamoto K, Ishimaru K, Yokoyama S, Tokashiki M. Large-scale perfusion culture process for suspended mammalian cells that uses a centrifuge with multiple setting zones. Appl Microbiol Biotechnol, 1996; 45: 454-7.

[21] Gorenflo VM, Smith L, Dedinsky B, Persson B, Piret JM. Scale-up and optimization of an acoustic filter for $200 \mathrm{~L} /$ day perfusion of a $\mathrm{CHO}$ cell culture. Biotechnol Bioeng, 2002; 80: 438-44.

http://dx.doi.org/10.1002/bit.10386

[22] Gorenflo VM, Angepat S, Bowen BD, Piret JM. Optimization of an acoustic cell filter with a novel Air-Backflush system. Biotechnol Prog, 2003; 19: 30-6.

http://dx.doi.org/10.1021/bp025625a

[23] Markx GH, Dyda PA, Pethig R. Dielectrophoretic separation of bacteria using a conductivity gradient. J Biotechnol, 1996; 51: $175-80$

http://dx.doi.org/10.1016/0168-1656(96)01617-3

[24] Liu R-M, Hunag JP. Theory of the dielectrophoretic behavior of clustered colloidal particles in two dimensions. Phys Lett A, 2004; 324: 458-64. http://dx.doi.org/10.1016/j.physleta.2004.03.004

[25] Mousavian SM, Najafi AF. Influence of geometry on separation efficiency in a hydrocyclone. Arch Appl Mech, 2009; 79: 1033-50. http://dx.doi.org/10.1007/s00419-008-0268-8

[26] Ortega-Rivas E. Separation techniques for solids and suspensions. Non-thermal food engineering operations, Food Engineering Series, 2012; 7: 131-97. http://dx.doi.org/10.1007/978-1-4614-2038-5 7
[27] Trawinski $\mathrm{H}$. Theory, application and practical operation of hydrocyclones. Eng Min J, 1976; 177: 115-27.

[28] Bretney E. Water purifier. U.S. Patent No. 543, 105, 1891.

[29] Wang $\mathrm{H}$, Zhang $\mathrm{Y}$, Wang J, Liu H. Cyclonic separation technology: Researches and developments. Chin J Chem Eng, 2012; 20(Pt 2): 212-9.

http://dx.doi.org/10.1016/S1004-9541(12)60381-4

[30] Oats WJ, Ozdemir O, Nguyen AV. Effect of mechanical and chemical clay removal by hydrocyclone and dispersants on coal flotation. Minerals Eng, 2010; 23: 413-9. http://dx.doi.org/10.1016/j.mineng.2009.12.002

[31] Schwerzler Gl. Recycling of glaze waste through hydrocyclone separation. Powder Technol, 2005; 160: 13540. http://dx.doi.org/10.1016/j.powtec.2005.08.032

[32] Dickey LC, Dallmer MF, Radewonuk ER, Parris N, Kurantz M, Craig Jr JC. Hydrocyclone separation of dry-milled corn. Cerel Chem, 1997; 74(Pt 5): 676-80.

http://dx.doi.org/10.1094/CCHEM.1997.74.5.676

[33] Yang Q, Wang H-L, Liu Y, Li Z-M. Solid/liquid separation performance of hydrocyclones with different cone combinations. Sep Pur Technol, 2010; 74: 271-9. http://dx.doi.org/10.1016/j.seppur.2010.06.014

[34] Wood JR, Grondin M, Karnis A. Characterization of mechanical pulp fines with a small hydrocyclone. 1. The principle and nature of the separation. J Pulp Paper Sci, 1991; 17: J1-J5.

[35] Young GAB, Wakley WD, Taggart DL, Andrews SL, Worrell JR. Oil-water separation using hydrocyclones-an experimental search for optimum dimensions. J Petrol Sci Eng, 1994; 11: 37-50.

[36] Dhamo N. Electrochemical oxidation of cyanide in the hydrocyclone cell. Waste Manag, 1996; 16: 257-61. http://dx.doi.org/10.1016/S0956-053X(96)00051-7

[37] Cilliers JJ, Harrison STL. The application of minihydrocyclones in the concentration of yeast suspension. Chem Eng J, 1997; 65: 21-6.

[38] Klima MS, Kim BH. Dense-medium separation of heavymetal particles from soil using a wide-angle hydrocyclone. $J$ Environ Sci Health, 1998; A33: 1325-40. http://dx.doi.org/10.1080/10934529809376791

[39] Moraes CAC, Hackenburg CM, Russo C, Medronho RA. Theoretical analysis of oily water hydrocyclones. In: Claxton D, Svarovsky L, Thew M, editors. Hydrocyclones. London \& Bury Saint Edmunds: Mechanical Eng Publication, 1996; p. 383-98.

[40] Marti S, Erdal FM, Shoham O, Shirazi S, Kouba GE. Analysis of gas carry-under in gas-liquid cylindrical cyclones. In: Claxton D, Svarovsky L, Thew M, editors, Hydrocyclones. London \& Bury Saint Edmunds: Mechanical Eng Publication, 1996; p. 399-421.

[41] Sierra C, Gallego JR, Afif E, Menéndez-Aguado JM, González-Coto F. Analysis of soil washing effectiveness to remediate a brownfield polluted with pyrite ashes. J Hazard Mater, 2010; 180: 602-8. http://dx.doi.org/10.1016/j.jhazmat.2010.04.075

[42] Rastogi K, Sahu JN, Meikap BC, Biswas MN. Removal of methylene blue from wastewater using fly ash as an adsorbent by hydrocyclone. J Hazard Mater, 2008; 158: 53140.

http://dx.doi.org/10.1016/j.jhazmat.2008.01.105

[43] Bader MSH. A hybrid liquid-phase precipitation (LPP) process in conjunction with membrane distillation (MD) for the treatment of the INEEL sodium-bearing liquid waste. $\mathrm{J}$ Hazard Mater, 2005; 121: 89-108.

http://dx.doi.org/10.1016/j.jhazmat.2005.01.017

[44] Schwier D, Hartge EU, Werther J, Gruhn G. Global sensitivity analysis in the flowsheet simulation of solids processes. Chem Eng Process, 2010; 49: 9-21. 
[45] Williford Jr. CW, Bricka RM, Foster CC. Reduction of suspended solids following hydroclassification of metalcontaminated soils. J Hazard Mater, 2002; 92: 63-75. http://dx.doi.org/10.1016/S0304-3894(01)00374-0

[46] Mann MJ. Full-scale and pilot-scale soil washing, J Hazard Mater, 1999; 66: 119-36. http://dx.doi.org/10.1016/S0304-3894(98)00207-6

[47] Anderson R, Rasor E, Van Ryn F. Particle size separation via soil washing to obtain volume reduction. J Hazard Mater, 1999; 66: 89-98.

http://dx.doi.org/10.1016/S0304-3894(98)00210-6

[48] Yurdem H, Demir V, Degirmencioglu A. Development of a mathematical model to predict clean water head losses in hydrocyclone filters in drip irrigation systems using dimensional analysis. Biosys Eng, 2010; 105: 495-506. http://dx.doi.org/10.1016/j.biosystemseng.2010.02.001

[49] Bai ZS, Wang HL, Tu ST. Purifying coke-cooling waste water. Chem Eng, 2010; 117: 40-1.

[50] Bai ZS, Wang HL, Tu ST. Oil-water separation using hydrocyclones enhanced by air bubbles. Chem Eng Res Design, 2011; 89: 55-9. http://dx.doi.org/10.1016/j.cherd.2010.04.012

[51] Wang H, Qian Z, Wang J, et al. A method and an equipment for waste water of cooling coke in USA. WO/2006/050,645, 2006.

[52] Emami S, Tabil LG, Tyler RT, Crerar WJ. Starch-protein separation from chickpea flour using a hydrocyclone. J Food Eng, 2007; 82: 460-5.

http://dx.doi.org/10.1016/j.jfoodeng.2007.03.002

[53] Nielson RJ, Moffitt CM, Watten BJ. Hydrocylonic separation of invasive New Zealand mudsnails from an aquaculture water source. Aquaculture, 2012; 326-329: 156-62. http://dx.doi.org/10.1016/j.aquaculture.2011.11.035

[54] Bendixen D, Rickwood D. Effects of hydrocyclones on the integrity of animal and microbial cells. Bioseparation, 1994; 4: 21-7.

[55] Pinto RV, Medronho R, Castilho L. Separation of $\mathrm{CHO}$ cells using hydrocyclones. Cytotechnology, 2008; 56: 57-67. http://dx.doi.org/10.1007/s10616-007-9108-x

[56] Min'kov LL, Krokhina AV, Dueck J. Hydrodynamic mechanisms of the influence of injection on the classification characteristics of a hydrocyclone. J Eng Phys Thermophys, 2011; 84(Pt 4): 807-19.

http://dx.doi.org/10.1007/s10891-011-0538-0

[57] Cilliers JJ. Particle size separation, Hydrocyclones for particle size separation. In: Poole C, Cooke M, editors. Encyclopedia of separation science, UK: Academic Press, 2000; p. 1819-25.

[58] Lynch AJ, Rao TC. Studies on the operating characteristics of hydrocyclone classifiers. Ind J Technol, 1968; 6: 106-14.

[59] Svarovsky L. Hydrocyclones. Holt: Reinehart and Winston Ltd; 1984.

[60] Ortega-Rivas E. Applications of the liquid cyclone in biological separations. Eng Life Sci, 2004; 4: 119-23. http://dx.doi.org/10.1002/elsc.200402004

[61] Dai GQ, Li JM, Chen WM. Numerical prediction of the liquid flow within a hydrocyclone. Chem Eng J, 1999; 74: 217-23. http://dx.doi.org/10.1016/S1385-8947(99)00044-3

[62] Nowakowski AF, Cullivan JC, Williams RA, Dyakowski T. Application of CFD to modelling of the flow in hydrocyclones. Is this a realizable option or still a research challenge? Minerals Eng, 2004; 17: 661-9. http://dx.doi.org/10.1016/j.mineng.2004.01.018

[63] Schuetz S, Mayer G, Bierdel M, Piesche M. Investigations on the flow and separation behaviour of hydrocyclones using computational fluid dynamics.Int J Miner Process, 2004; 73: 229-37.

http://dx.doi.org/10.1016/S0301-7516(03)00075-9
[64] Narasimha M, Sripriya R, Banerjee PK. CFD modelling of hydrocyclone-prediction of cut size. Inter J Miner Process, 2005; 75: 53-68.

http://dx.doi.org/10.1016/j.minpro.2004.04.008

[65] Sripriya R, Kaulaskar M, Chakraborty S, Meikap B. Studies on the performance of a hydrocyclone and modeling for flow characterization in presence and absence of air core. Chem Eng Sci, 2007; 62(Pt 22): 6391-6402. http://dx.doi.org/10.1016/i.ces.2007.07.046

[66] Davailles A, Climent E, Bourgeois F. Fundamental understanding of swirling flow pattern in hydrocyclones. Sep Pur Technol, 2012; 92: 152-60. http://dx.doi.org/10.1016/j.seppur.2011.12.011

[67] Rietema K. Performance and design of hydrocyclone. Chem Eng Sci, 1961; 15: 298-325.

[68] Heiskanen K. Particle Classification. London: Chapman \& Hall; 1993.

[69] Chakraborti N, Miller JD. Fluid flow in hydrocyclones: A critical review. Mineral Process Extract Metall Rev, 1992; 211-44.

http://dx.doi.org/10.1080/08827509208914207

[70] Jirun X, Qian L, Jicun Q. Studying the flow field in a hydrocyclone with no forced vortex. Part II: Turbulence. Filtr Separat, 1990; 27: 356-9. http://dx.doi.org/10.1016/0015-1882(90)80369-V

[71] Chu L-Y, Luo Q. Hydrocyclone with high separation sharpness. Filtr Separat, 1994; 31: 733-6. http://dx.doi.org/10.1016/0015-1882(94)80156-8

[72] Bai Z-S, Wang H-L, Tu S-T. Removal of catalyst from oil slurry by hydrocyclone. Sep Sci Technol, 2009; 44: 2067-77. http://dx.doi.org/10.1080/01496390902880149

[73] Kashiwaya K, Noumachi T, Hiroyoshi N, Ito M, Tsunekawa $\mathrm{M}$. Effect of particle shape on hydrocyclone classification. Powder Technol, 2012; 226: 147-56. http://dx.doi.org/10.1016/j.powtec.2012.04.036

[74] Chen W, Zydek N, Parma F. Evaluation of hydrocyclone models for practical applications. Chem Eng J, 2000; 80: 295-303.

http://dx.doi.org/10.1016/S1383-5866(00)00105-2

[75] Chu L-Y, Chen W-M, Lee X-Z. Enhancement of hydrocyclone performance by controlling the inside turbulence structure. Chem Eng Sci, 2002; 57: 207-12. http://dx.doi.org/10.1016/S0009-2509(01)00364-5

[76] Lynch AJ, Rao TC, Prisbrey KA. The influence of hydrocyclone diameter on reduced efficiency curves. Inter J Miner Process, 1974; 1: 173-81. http://dx.doi.org/10.1016/0301-7516(74)90013-1

[77] Lynch AJ, Rao TC, Bailey CW. The influence of design and operating variables on the capacities of hydrocyclone classifiers. Inter J Miner Process, 1975; 2: 29-37.

http://dx.doi.org/10.1016/0301-7516(75)90010-1

[78] Trawinski $\mathrm{H}$. The separation process in the hydrocyclone. Miner Process, 1995; 36: 410-7.

[79] Kurtela Z, Komadina P. Application of hydrocyclone and UV radiation as a ballast water treatment method. Sci J Traffic Transport Res, 2010; 22(Pt 3): 183-91. http://dx.doi.org/10.7307/ptt.v22i3.274

[80] Abu-Khader MM, Badran O, Attarakih M. Ballast water treatment technologies: hydrocyclonic a viable option. Clean Technol Environmen Policy, 2011; 13: 403-13. http://dx.doi.org/10.1007/s10098-010-0325-1

[81] Show K-Y, Lee D-J, Chang J-S. Algal biomass dehydration. Bioresource Technol, 2013; 135: 720-9. http://dx.doi.org/10.1016/j.biortech.2012.08.021

[82] Seccombe P. Development of a hydrocyclone bioreactor for the continuous culture of immobilized yeast cells. J Chem Technol Biotechnol, 1991; 51: 284-5. http://dx.doi.org/10.1002/jctb.280510227 
[83] Yuan H, Rickwood D, Smyth IC, Thew MT. An investigation into the possible use of hydrocyclones for the removal of yeast from beer. Bioseparation, 1996; 6: 159-63.

[84] Weuster-Botz D, Hünnekes E, Hartbrich A. Scale-up and application of a cyclone reactor for fermentation processes. Bioprocess Eng, 1998; 18: 433-8. http://dx.doi.org/10.1007/s004490050467

[85] Matta VM, Medronho RA. A new method for yeast recovery in batch ethanol fermentation: Filter aid filtration followed by separation of yeast from filter aid using hydrocyclones. Bioseparation, 2000; 9: 43-53. http://dx.doi.org/10.1023/A:1008145419175

[86] Medronho RA, Schuetze J, Deckwer W-D. Numerical simulation of hydrocyclones for cell separation. Lat Am App Res, 2005; 35: 1-8.

[87] Habibian M, Pazouki M, Ghanaie H, Abbaspour-Sani A. Application of hydrocyclone for removal of yeasts from alcohol fermentations broth. Chem Eng J, 2008; 138: 30-4. http://dx.doi.org/10.1016/j.cej.2007.05.025

[88] Bicalho IC, Mognon JL, Shimoyama J, Ataíde CH, Duarte CR. Separation of yeast from alcoholic fermentation in small hydrocyclones. Sep Pur Technol, 2012; 87: 62-70. http://dx.doi.org/10.1016/j.seppur.2011.11.023

[89] Pinto AA, Bicalho IC, Mognon JL, Duarte CR, Ataíde CH. Separation of Saccharomyces cerevisiae from alcoholic fermentation broth by two commercial hydrocyclones. Sep Pur Technol, 2013, 120: 69-77.

http://dx.doi.org/10.1016/i.seppur.2013.09.013

[90] Castilho LR, Medronho RA. Animal cell separation. In: Castilho LR, Moraes AM, Augusto EFP, Butler M, editors. Animal cell technology: From biopharmaceuticals to gene therapy. New York: Taylor \& Francis Group, 2008; p. 273-93.

[91] Lübberstedt M, Anspach FB, Deckwer W-D, Medronho RA. Abtrennung tierischer Zellen mit Hydrozyklonen. Chem Eng Tech, 2000; 72: 1089-90.

http://dx.doi.org/10.1002/1522-2640(200009)72:9<1089::AIDCITE10890>3.0.CO;2-O

[92] Jockwer A, Medronho RA, Wagner R, Anspach FB, Deckwer $W-D$. The use of hydrocyclones for mammalian cell retention in perfusion bioreactors. In: Linder-Olsson E, Chatzissavidou $\mathrm{N}$, Lüllau E, editors. Animal cell technology: From target to market. Dodrecht: Kluwer Academic Publishers, 2001; p. 301-5.

http://dx.doi.org/10.1007/978-94-010-0369-8 69

[93] Deckwer W-D, Medronho RA, Anspach B, Lübberstedt M. Method for separating viable cells from cell suspensions. US Patent 6,878,545 B2, WO 2001/85902. European Patent, PCT/EP 01/03665, 2005.
[94] Elsayed EA, Piehl G-W, Nothnagel J, Medronho RA, Deckwer W-D, Wagner R. Use of hydrocyclone as an efficient tool for cell retention in perfusion cultures. In: Gòdia $\mathrm{F}$, Fussenegger $\mathrm{M}$, editors, Animal cell technology meets genomics. Netherlands: Springer, 2005; p.679-82. http://dx.doi.org/10.1007/1-4020-3103-3 139

[95] Elsayed EA, Medronho RA, Wagner R, Deckwer W-D. Use of hydrocyclones for mammalian cell retention: separation efficiency and cell viability (Part 1). Eng Life Sci, 2006; 6(Pt 4): 347-54. http://dx.doi.org/10.1002/elsc.200620137

[96] Pinto RCV, Medronho RA, Castilho LR. The effects of cell separation with hydrocyclones on the viability of $\mathrm{CHO}$ cells, In: Smith R, editor, Cell technology for cell products. Netherlands: Springer, 2007; p. 745-8. http://dx.doi.org/10.1007/978-1-4020-5476-1 134

[97] Schröder B, Elsayed EA, Olownia J, Wagner R. Advantages of hydrodynamic cell separation in industrial cell culture processes, In: Noll T, editor, Cells and culture. Netherlands: Springer, 2010; p.657-64.

http://dx.doi.org/10.1007/978-90-481-3419-9 113

[98] Elsayed EA, Wagner R. Application of hydrocyclones for continuous cultivation of SP-2/0 cells in perfusion bioreactors: Effect of hydrocyclone operating pressure. BMC Proceed, 2011; 5(Suppl 8): P65.

http://dx.doi.org/10.1186/1753-6561-5-S8-P65

[99] Elsayed EA, Ramalho LAG, Castilho LR, Medronho RA. Feed flow pulsation in the separation of $\mathrm{CHO}$ cells in hydrocyclones: effects of pressure drop and pumphead type on separation efficiency and cell viability. In: Jenkins $N$, Barron Niall, Alves $P$, editors. Proceedings of the 21st Annual Meeting of the European Society for Animal Cell Technology (ESACT), Dublin, Ireland; 2012: p. 341-4. http://dx.doi.org/10.1007/978-94-007-0884-6 53

[100] Rao TC, Nageswararao K, Lynch AJ. Influence of feed inlet diameter on the hydrocyclone behaviour. Inter $\mathrm{J}$ Miner Process, 1976; 3: 357-63.

[101] Statie EC, Salcudean ME, Gartshore IS.The influence of hydrocyclone geometry on separation and fibre classification. Filtr Sep, 2001; 38: 36-41. http://dx.doi.org/10.1016/S0015-1882(01)80380-3

[102] Chen C, Wang H-L, Gan G-H, Wang J-Y, Huang C. Pressure drop and flow distribution in a group of paralle hydrocyclones: Z-Z-type arrangement. Filtr Sep, 2013; 108: 15-27.

http://dx.doi.org/10.1016/j.seppur.2013.01.038

Received on 01-12-2013

DOI: http://dx.doi.org/10.6000/1927-3037.2013.02.04.2

(C) 2013 Elsayed and Wadaan; Licensee Lifescience Global.

This is an open access article licensed under the terms of the Creative Commons Attribution Non-Commercial License (http://creativecommons.org/licenses/by-nc/3.0/) which permits unrestricted, non-commercial use, distribution and reproduction in any medium, provided the work is properly cited. 